\title{
Study of patterns and drives of utilization and Out-of-pocket Health Expenditure in selected groups in Cairo-Egypt
}

\author{
Mohamed H Shehata ${ }^{1 *}$, Maha Emad Ibramin ${ }^{2}$, Hala Mohamed ELDamanhoury ${ }^{3}$ \\ ${ }^{1}$ Family Medicine department, Faculty of Medicine, Helwan University \\ ${ }^{2}$ Rheumatology and Rehabilitation department, Faculty of Medicine, Suez Canal University \\ ${ }^{3}$ Obstetrics /Gynecology consultant Curative Medicine Department, New Cairo District. Ministry of Health
}

\begin{abstract}
Background: Despite wide coverage of low-cost public health services, Egyptians seem to have different preferences and perceptions regarding the variant health care providers in the country. This study aims at exploring their perceptions and drives towards various providers and to describe the pattern of utilization and out of pocket expenditure of health. Patients and methods: A qualitative research was conducted to analyze the outputs of focus groups and interviews to selected groups of insured and non-insured users in rural and urban areas. Results: Participants consider public facilities if the case is an emergency case or requires prolonged hospitalization. However, they still do not trust the doctors in the public sector. As for the Health insurance Authority, participants focus on getting their medications for chronic diseases and conduct their routine periodic investigations. Participants have poor awareness regarding the value of preventive healthcare and utilize the accessible primary healthcare facilities mainly for vaccination and Antenatal care. However, if they decide to seek medical care, they prefer cheap private polyclinics and pharmacies. They trust these two types of providers and think that they handle the properly with the lowest cost. Conclusion: Providers need to put more effort to build trust with their patients and decision makers need to consider the users' perceptions regarding the provided services. The government should invest more to campaigns of awareness towards the value of cheap and accessible health services at the level of primary care.
\end{abstract}

Keywords: perceptions, health-insurance, impoverishment, healthcare, primary care

\section{Introduction}

Egypt provides massive subsidy programs that cover food and energy. In the health sector, subsidized health services depend on the general tax revenue and aims at providing free healthcare to all citizens. Public health spending in Egypt accounts for nearly $6 \%$ of the total public spending. This is far behind the Abuja target of allocating $15 \%$ of total government spending to health. The subsidized health system is under continuous population pressure resulting from the significant increase in life expectancy and the high fertility rates. Consequently, this has led to increasing use of private health facilities, which require fees $(\mathbf{1}, \mathbf{2})$

* Corresponding author. E-mail address: mhany1eg@yahoo.com 
There is a need for a healthcare service quality model that takes into consideration a complete coverage of the three dimensions that consumers use in evaluating healthcare service quality. These dimensions are: client quality, professional quality and management quality, and the client satisfaction is the most important. Despite the accessible relatively low cost public health facilitates and 25\% insurance coverage, many Egyptians perceive government health services as low quality. (3)

\section{Patients and Methods}

Qualitative study, applied a mixed methods approach where in-depth interviews and Focus groups discussions where used.

The aim of the study was to aid decision makers for better planning of the health insurance system. The objectives were (1) to understand the perceptions of Egyptians towards health services and (2) to explore their drives towards using certain health services

The focus group discussions and in-depth interviews were recorded and transcribed. Then the researchers used NVIVO $\left(10^{\text {th }}\right.$ version) software to analyze the results.

The sample included participants from rural and urban areas. Of these two groups the researches were keen to include ensured as well as uninsured citizens.

The researchers developed an interview guide and another guide for focus group discussions in order to cover the research objectives.

Two focus group discussions took place ( 2 hours each) for a group of patients who were in the waiting area of one general hospital and a second one were conducted to a mixed group of manual workers and employees in a mosque after prayers. Other participants from other socioeconomic classes (around 12) were interviewed individually using the interview guide.

\section{Results}

\section{Drives and preferences of health care facilities}

On interviewing respondents from middle to low socioeconomic class regarding their preferences of service providers when they get sick, they declared that their preferred choices are the pharmacies followed by cheap polyclinics. A participant said: "Some people try pharmacies first and if not improved, they go to private providers"

When the researchers tried to explore their reason for choosing a provider than others they concluded that their decision varies according to the accessibility, seriousness of symptoms, cost and their previous experience. They prefer to go directly to pharmacies because of the positive 
recurrent experiences with effective treatments the give fast satisfactory results. Many of them described pharmacies as cheap and near and perceive the pharmacist as a "good" person.

Only in the cases of emergency respondents prefer university hospitals or general hospitals. However, most of them showed no sufficient interest in preventive aspects as they only seek medical help if the sick person is a child or has severe symptoms.

Based on the focus groups' discussions; the main drives of preferences of people towards different health facilities were:

\section{Convenience:}

The participants considered private healthcare services as more accessible and affordable. Pharmacies again fulfilled most of the people's drives for seeking help when diseased with mild illnesses. Non availability of the drugs and medical supplies in public hospitals was an essential factor to prefer other providers over them. A participant said "The pharmacist gives me a cheap bottle of Medicine for few pounds compared to extremely expensive services elsewhere that might be up to 150 pounds". When asked about utilizing the nearby Family Practice Unit and that it is also near to them and cheap, the informants said that it has no doctors at night and we still have to pay for the medicines.

\section{Paying less:}

As regards their ability to pay, it was a turning point in either to pay for private services, go to cheap public hospitals or don't ask for any help. This has created a group of unmet health needs that are merely known but still not investigated.

3. Poverty and lack of health insurance doesn't shape people's drives. They prefer the private providers specifically in high burden diseases, unless they are completely unable to pay then they choose public providers.

4. Trust in the value of private providers for being keen to introduce better services to attract clients. On the other hand, participants perceived public healthcare facilities as deficient of medical supplies, medications and intensive care equipment. Some participants said" for example, I don't think that there is any public hospital that has good incubators for the premature neonates". They also think that there is lack of accountability and absence of senior staff of doctors. Another important point concerning the stereotyping of the trust, we have discovered in 
some cases, misconceptions originated from the side of health care providers that shape the awareness of people and affect their health seeking pattern and out of pockets payment.

\section{Catastrophic expenditure}

Some respondents needed to pay more than 2500 a day for an Intensive care bed only plus other expenses including purchasing blood products from the black market and transport fees as well as illegal bribes to be able to access their relatives in the hospital. They stated that they were ready to sell their homes and burrowed a lot of money plus the financial aid by others

Others had to take lawns and use aids from relatives to cover the cost of serious eye operation for a child whom his father lost a limb in a recent accident and is not insured. Another vase sold something from her house to cover the medicine cost for her bleeding problem and was very emotional about this

\section{Ordinary Out-of-pocket (OOP)}

Many patients buy their preferred medicine and refuse to get the insurance medicines. The cost of transportation from Upper Egypt and from other places is also very high from them to get services that are centralized in Cairo and sometimes exceeds the cost of medicine. Even in public hospitals patients have to pay to get basic things such as bed covers and medications. In some public hospitals patients perceive that doctors make them pay money for unnecessary equipment's or medicines. Many pay bribes to personnel to get to the doctors faster (in almost all types of services).

Participants complained that private hospitals obliged them to put very high deposit even in cases of emergency. Participants revealed that sometimes they feel they can't get the best services because of their limited financial abilities

\section{Patterns of utilization:}

People tend to utilize insurance to get medicines "that they demand" especially for patients with chronic diseases who visit the hospital on regular monthly/quarterly basis. Others use the insurance to perform requested investigations but not usually to get consultations there. 
They tend to be specific about getting the best benefits from the insurance and in the meantime avoiding as much the daunting/time consuming routine steps. Sometimes patients perceive general hospitals as a suitable place for getting emergency services

\section{Perceptions about general hospitals}

\section{Positive}

Some patients perceive general hospitals as a place with "good" physicians, low cost, free medications with the optimum investigations available. One of the respondents used the general hospital for his Son's tonsillectomy operation which cost them almost nothing and this was a very positive aspect

\section{Negative}

Most of the participants thought of words such as negligence, loss of dignity and chaos when describing general hospitals. They also perceive the medical staff working there as young, less experienced and inconsiderate. Some of them also were bothered by encountering a different doctor every time they go to the general hospital

Many described the process of getting a service such as admission as a long, routine with many steps experience. They also complained of poor follow-up and lack of control there

Some respondents from higher social classes perceived public hospitals as field for trials and described the medicines there as cheap ones with low levels of active ingredients

Others describe the services as of low quality and they also stated that you have to pay inside the hospital to get basic services and that sometimes the medical staff get fees from them illegally either directly or indirectly .Respondents say that; experienced consultants are hard to reach in public hospital and rarely show.Many describe the treatment as no good and that don't get cured, their health even get worse

\section{Perceptions about primary care services}

\section{Positive}

Accessible and cheap 


\section{Negative}

They summarized the drawbacks of primary care units as having no specialized doctors, no diverse services, only good for well-baby and antenatal care; doctors also tend to run very quick examinations from the point of view of the respondents. They are also apprehensive of young, not well-trained staff

\section{Perceptions about private hospitals}

\section{Positive}

What patients had consensus on regarding private hospitals is the good humanistic communication.

They also trusted the "brand" and thought that the staff in the private hospitals and well-trained with experience that they can trust

Being examined in a timely manner is another advantage of private hospitals

\section{Negative}

Inhuman dealing with emergency cases with requesting a relatively high amount of money as a deposit before accepting the patient was a major disadvantage of dealing with private hospitals as well as the unexplained expenses and very high cost

Some very reputable hospitals also lack basic and important equipment.

It is also not unusual to pay a lot of money and get a wrong diagnosis from their perspective

Figure (1) represents the word cloud that was generated by the Nvivo software to represent the qualitative analysis of the study results.

\section{Discussion}

The overall purpose of this study was to explore patterns and drives of out of pocket expenditure. Through experiences of people from different social classes with much emphasis on the working class and poor patients, researchers tried to assess the factors underlying their choice of the facility and whether it depends on their perceptions of quality of care received, or there are other determining factors. 
Many of the participants in our study preferred pharmacies followed by cheap private facilities. This is in partial consistence with findings of CAPMAS 2015 as 51.6\% of Egyptians go to private clinics, $32.3 \%$ prefer pharmacies while nearly $10 \%$ use governmental health services

Our study participants revealed that they are obliged many time to pay out of pocket money to get proper services. In other instances, they are at risk of impoverishment. This is consistent with (Alam et al., 2014) who described that many households in Egypt rely on out-of-pocket financing which increases the risk of becoming impoverished if the out-of-pocket payments were substantial and for prolonged periods ${ }^{(4)}$.

In 2010, Shawky concluded that despite that Health Insurance Organization provides compulsory insurance to $55 \%$ of the population that is funded mainly from insurance premiums and copayments, less than half of the insured are really benefiting from the insurance scheme which is almost consistent with our findings as the health insurance organization facilities are not considered as a preferred service provider due to perceived low quality, inhuman services. ${ }^{(5)}$

The limitations of the study are similar to limitations of any qualitative study. The results cannot be generalized to other populations and the researchers' perceptions affect the study outputs.

\section{Conclusion}

Our findings highlight the urge for Health sector quality improvement at different levels. Users should be considered as partners while planning for healthcare financing and delivery and their perceptions should be the focus of any work in this domain. Raising the public awareness towards the benefits and uses of primary care is also very important to improve accessibility and service outcomes. Governmental efforts have to be done to establish family medicine model and create awareness with the preventive medicine.

\section{References}

1. El Zanaty F, Way A. Egypt Demographic and Health Survey 2005. Cairo, Ministry of Health and Population, National Population Council, El-Zanaty and Associates and ORC Macro, 2005.Available at: https://www.dhsprogram.com/pubs/pdf/FR176/FR176.pdf. Accessed on 20 November 2017.

2. Benova L, Campbell O, Ploubidis G. Socio-economic gradients in maternal and child health-seeking behaviours in Egypt: systematic literature review and evidence synthesis. 


\section{PloS}

one.

2014;9(3):e93032.Available

at:

http://journals.plos.org/plosone/article?id=10.1371/journal.pone.0093032.

3. EMRO (2006) Health Systems Profile- Egypt Regional Health Systems Observatory. WHO publications.

Available

at: http://apps.who.int/medicinedocs/documents/s17293e/s17293e.pdf. Accessed on 20 November 2017.

4. Alam K, Mahal A. Economic impacts of health shocks on households in low and middle income countries: a review of the literature. Globalization and health. 2014 ;10(1):21.Avai;able

at: https://globalizationandhealth.biomedcentral.com/articles/10.1186/1744-8603-10-21. Accessed on 20 November 2017.

5. Shawky S. Could the employment-based targeting approach serve Egypt in moving towards a social health insurance model? Eastern Mediterranean Health Journal.2010;16: 663.Available

at: https://pdfs.semanticscholar.org/0d41/2ea64cbea764d3e05adb9c28dd0e23afbc65.pdf. Accessed on 20 November 2017.

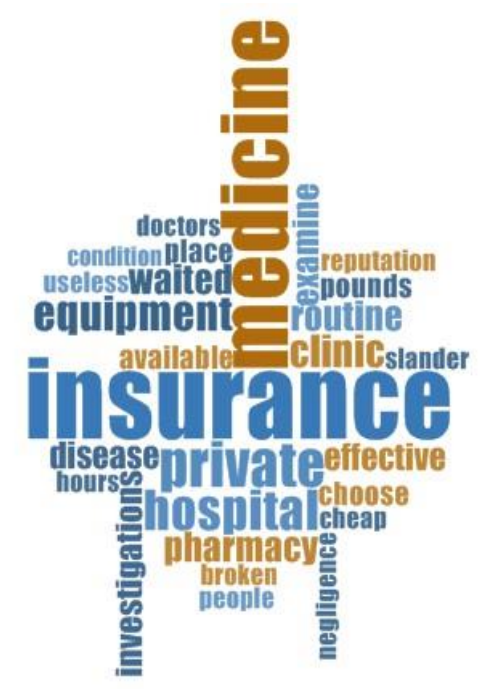

Figure (1): word cloud of the current study 


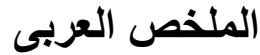 \\ در اسة أنماط و دوافع الاستخدام و الانفاق الشخصي على الصحه في مجموعات منتقاة بالقاهرة ـ مصر}

محمد هانى شحاته(1) - مها عماد ابر اهيم (2)ـ هاله محمد الدمنهورى(3) (1) استاذ مساعد طب اسره-جامعه حلو ان مدان

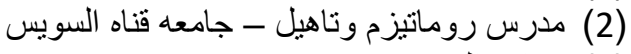
(3) وزاره الصحه

مقدمة و هدف الدراسة: بالر غم من التغطية الو اسعة للخدمات الصحية منخفضة التكلفة من خلال القطاع العام الا أنه يبدو أن

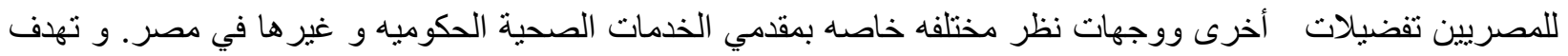
الدر اسه الى استكثاف وجهات نظر و تفضيلات و دو افع المشاركين بالدر اسة الخاصة باستخدام الخدمات الصحية و الانفاق الصحه. على الجيبي طرق البحث: بحث نوعي تم تطبيقه لتحليل مخرجات المقابلات الثخصية و مجمو عات النقاش البؤرية لمجمو عات مختارة من الثنا الريف و الحضر مع مر اعاة أن تتضمن عينة الدراسة اشخاصا يتمتعون بالتأمين الصحي و اخرين مئن غير مؤمن عليهم

نتائج البحث: اعتبر المشاركون أن الأماكن الحكومية مناسبة لحالات الطوارئ و الحالات التي تستدعي حجز المريض بصور

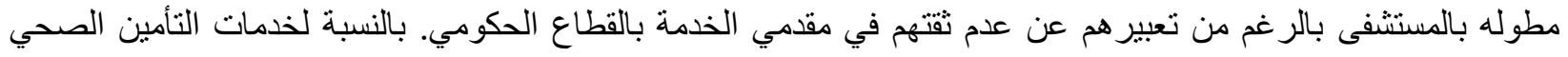

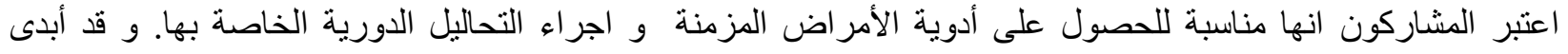

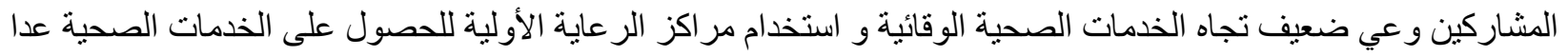

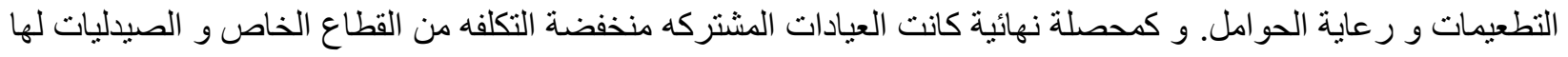
الأفضلية عند مرض أحد أفراد الأسرة و عند سؤ الهم عن الأسباب أفادوا بثقتهم في مقدمي الخدمة و انخفاض التهنة التكلفة.

و خلصت الدر اسة الى أن مقدمي الخدمة يحتاجون الى وضع جهد أكبر في بناء التقه مع المستفيدين و يحتاج صناع القرار أيضا

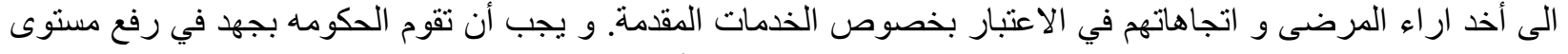

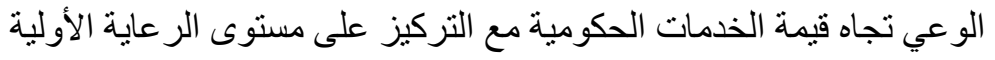

